\title{
Changes of Fatigue Fracture Properties on the Flow Direction of Injection-Molded PP Sheets
}

\author{
○正 邱 建輝 (秋田県大) 正 熊沢鉄雄 (秋田県大) 正 中山 昇 (秋田県大)
}

Jianhui QIU, Akita Prefectural University, 84-4Tsuchiya-Ebinokuchi, Honjyo, Akita, 015-0055 Japan Tetsuo KUMAZAWA, Akita Prefectural University Noboru NAKAYAMA, Akita Prefectural University

\section{1. はじめに}

ポリプロピレン(PP)は軽量、安価で、リサイクルし易いた め、家電、自動車部品に採用されつつある ${ }^{1)}$ 。特に自動車用 プラスチック材料として、近年、使用量が急激に増えてい る ${ }^{1)}$ 。しかし、自動車バンパー、インストルパネル等のよう な薄長い構造部品やファンシュラウドなど繰返し熱応力を 受けるエンジン内部材、更にPP 系複合材料の開発 ${ }^{2)}$ にる 用途を拡大した繰返し負荷を受ける構造部品に使用する場 合は、その力学特性を十分に把握する必要がある。本研究 ではそのような細長い射出成形品の流れ方向における材料 の内部構造と疲労破壊特性との関連性を明らかにし、PPを より広範囲に応用するために、その信頼性に関わるデータ を提供することを目的としている。

\section{2. 実験方法}

\section{$2 \cdot 1$ 供試材料と試験片}

市販の PP ペレット(三菱化学 ホモポリプロビレン MA2)を 用いて、射出成形機(日本製鋼(株)製、J75SS2)により JIS1 号 ダンベル型試験片(Fig. 1)を成形した。成形条件としてはノ ズル温度 $200^{\circ} \mathrm{C} 、$ 金型温度 $40^{\circ} \mathrm{C}$ 、射出速度 $2.2 、 22 、 55 \mathrm{~cm}^{3} / \mathrm{sec}$ 、 射出圧力 $56.4 \mathrm{MPa}$ 、冷却時間 $20 \mathrm{sec}$ である。

\section{$2 \cdot 2$ 内部組織の観察}

射出成形した試料の内部モルフォロジーを調べるため、 試料幅の中央部からロータリーミクロトーム(LEICA(株)製、 RM2145)で流れ方向に沿ってゲート側の曲がり部から反対 側の曲がり部までそれぞれ試料幅 $2 \mathrm{~mm} \times$ 長手方向 $(10 \mathrm{~mm})$ ×厚さ $10 \mu \mathrm{m}$ の薄片を切り出した。また、偏光光学顕微鏡 (NIKON(株)製、ECLIPSE ME600D)により内部構造を観察 した。

\section{$2 \cdot 3$ 硬さの測定}

流れ方向における試料断面各層(スキン、中間、コア)の力 学特性の違いを調べるため、ダイナミック超微小硬度計(島 津製作所(株)製、DUH-200)により硬さを測定した。測定用 試料は試験片平行部の中央から切出し、測定面はロータリ ーミクロトームで切出した後、エメリー紙で研磨し、バフ 研磨で仕上げた。測定箇所はゲート側から反対側まで $10 \mathrm{~mm}$ の間隔で 7 箘所である。硬さ測定は荷重 $0.098 \mathrm{~N}$ 、負荷速度 $2.65 \times 10^{-3} \mathrm{~N} / \mathrm{sec}$ 、保持時間 $5 \mathrm{sec}$ 、室温 $\left(24 \pm 1^{\circ} \mathrm{C}\right)$ で行った。硬 さは次の式(1)で算出した。

$$
\mathrm{DH}=\alpha \mathrm{P} / \mathrm{D}^{2}
$$

ただし、P は試験荷重、D は押し込み深さ、 $\alpha=37.838(115$ 度三角錐圧子)

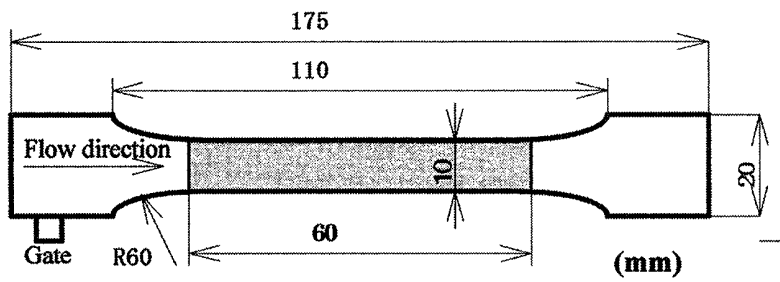

Fig.1 Specimen geometry

\section{4 疲労試験}

実験装置は疲労試験機(オリエンテック(株)製、VFA-1KNA) である。この試験機により応力制御条件下での疲労過程中にお ける貯藏弾性率 $\mathrm{E}^{\prime}$ 、損失弾性率 $\mathrm{E}$ ”、力学的損失正接 $\tan \delta$ 、試 料の伸び Ld、伸び振幅 $\Delta \mathrm{L}$ および試料の表面温度 Ts などを連 続的に測定した。試験片の流動方向における疲労破壊特性を調 べるために、平行部 $(60 \mathrm{~mm})$ を $20 \mathrm{~mm}$ ずつ三等分に分けた試験 片を用いた。試料長(チャック間距離) $20 \mathrm{~mm}$ 、周波数 $5 \mathrm{~Hz}$ 、引 張片振り正弦波の応力比 0.02 である。また、PPの力学特性が 試験温度の変動を受けやすいので、各部分の疲労破壊特性の違 いをより正確に検出するために、試験温度を $20 \pm 0.1^{\circ} \mathrm{C}$ (最初 $20 \mathrm{~min}$ の最大波動範囲 $19.8 \sim 20.4^{\circ} \mathrm{C}$ である)の範用で試験終了ま で精密にコントロールした。温度制御用液体窒素タンク容量の 制限により長時間の試験ができないので、テストを行って、負 荷応力振幅は $15 \mathrm{MPa} 、 16 \mathrm{MPa}$ に設定し、試料の相対疲労寿命 を求めた。

\section{3. 結果および考察}

\section{$3 \cdot 1$ 内部構造}

Fig.2 に流れ方向における試料断面の偏光顕微鏡写真を示 した。試料の左表面は結晶が見えない白いスキン層であり、 その隣の黒く観察される部分は中間層で、更に右側の結晶 が観察される部分はコア層である。流れ方向に向かって、 このような 3 層構造は光学顕微鏡での観察では明暸な変化 が認めなかった。

一方、射出成形速度の増加はスキン層と中間層の厚さが $520 \rightarrow 340 \rightarrow 280 \mu \mathrm{m}$ のように薄くなるのに対して、コア層は 次第に厚くなった。これは射出成形する際に、射出速度が 速いほど、樹脂の充填する時間が短く、せん断応力を受け ながら形成する中間層は比較的に短時間で凝固するので薄 くなることによるものである。

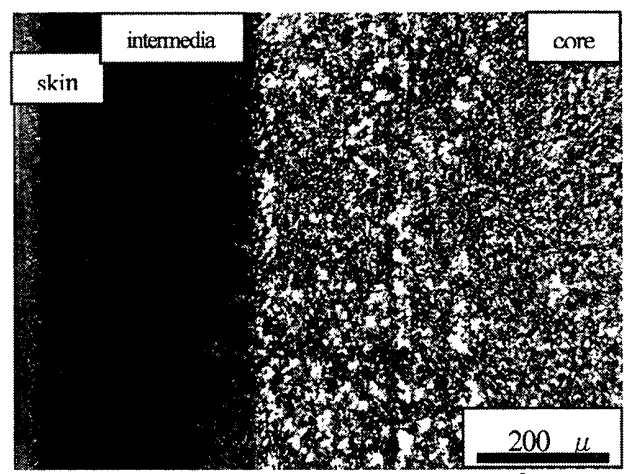

Fig.2. Micrographs of cross section $\left(22 \mathrm{~cm}^{3} / \mathrm{s}\right)$

\section{$3 \cdot 2$ 硬度分布の変化}

Fig.3 に流れ方向における各層の硬さ変化を示し、Fig.4に 流れ方向における各試料断面の微小硬さ分布を示した。図 より、流れ方向に向かって各層の硬度が低下寸ることがわ かる。その変化範囲は、3 層の中ではスキン層が約 8.1 7.3 で最も大きい。一方、Fig.4により各試料断面の硬さは、ス キン層 $\rightarrow コ ア$ 層 $\rightarrow$ 中間層の順に高くなる。また、ゲート側

日本機械学会東北支部第39期秋季講演会講演論文集 


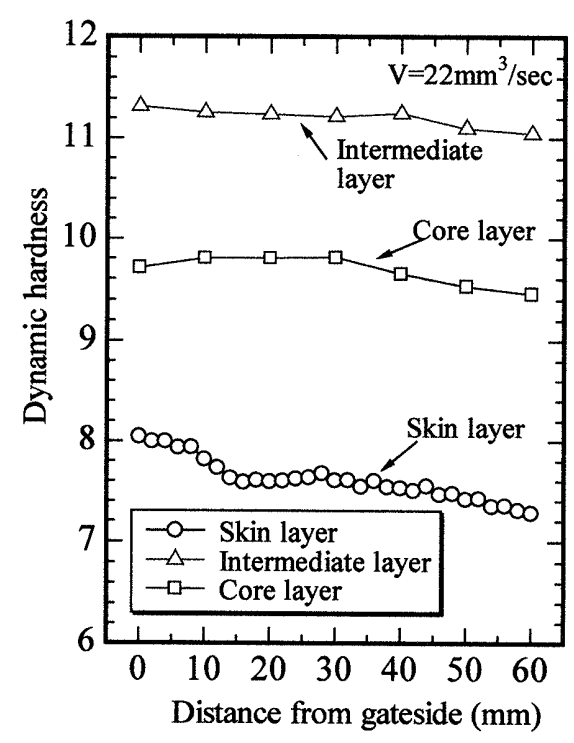

Fig.3 Distribution of hardness in Flow Direction

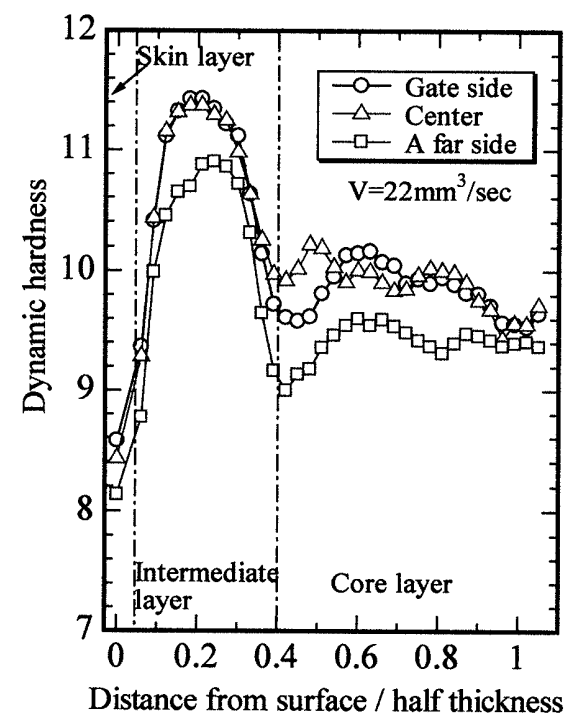

Fig.4 Distribution of hardness in cross section

と中央部における各層の硬さ分布と大きさの差は小さいが、 反対側の硬さでは低かった。つまり、ゲートから最も遠い ところ硬さは一番小さい。また、成形速度が遅いほど(例え ぼ、 $2.2 \mathrm{~cm}^{3} / \mathrm{sec}$ )、試料の中間層が厚くなり、硬さも高くなる。

以上のような射出成形試料断面および流れ方向における 硬さの分布となる要因は射出成形する際に材料内部構造の 形成機構によるものと考えられる。

\section{3 疲労破壊特性}

Fig.5(a)(b)に疲労破壊過程における $\tan \delta$ E'の変化および試 料伸び $\mathrm{Ld}$ と伸び振幅 $\Delta \mathrm{L}$ の変化を示した。各試料では、負荷

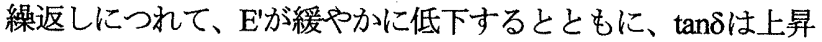

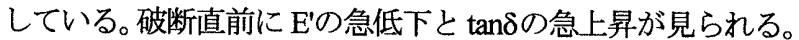
また、試料の伸び Ld と伸び振幅 $\Delta \mathrm{L}$ も $\tan \delta$ の変化傾向と同様 である。流れ方向における各パラメータの変化は、E'のレベル が低下に、 $\tan \delta$ のベルは上昇する。この傾向は疲労に進むに つれて次第に大きくなる。つまり、試料の疲労破壊は流れ方向 に沿ってより延性的になり、疲労寿命も短くなる。この傾向は 前述した断面の硬さ変化とほぼ一致している。

以上の結果は流れ方向の流動状態と射出成形速度による試 料の内部構造等に関係があるが、主に前述した中間層の厚さの

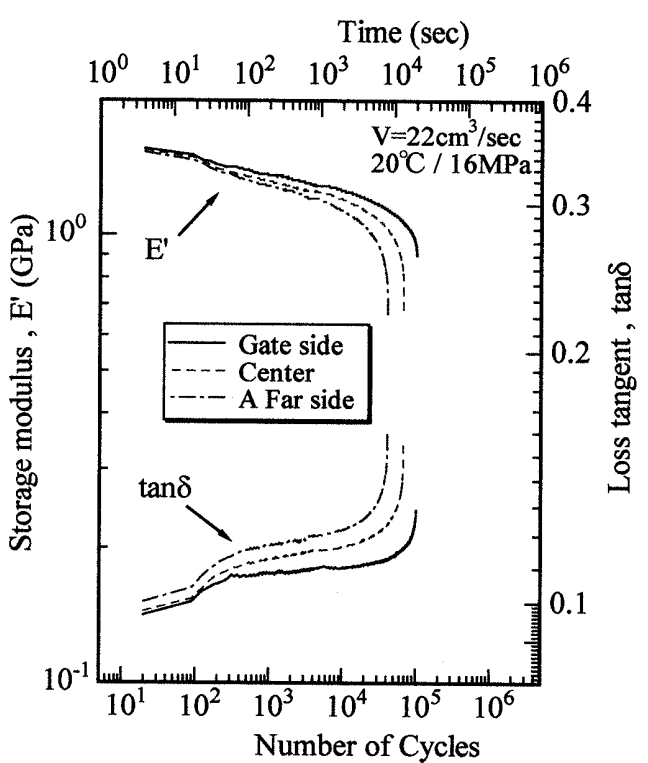

(a) Variations in E' and tan $\delta$ during fatigue process Time (sec)

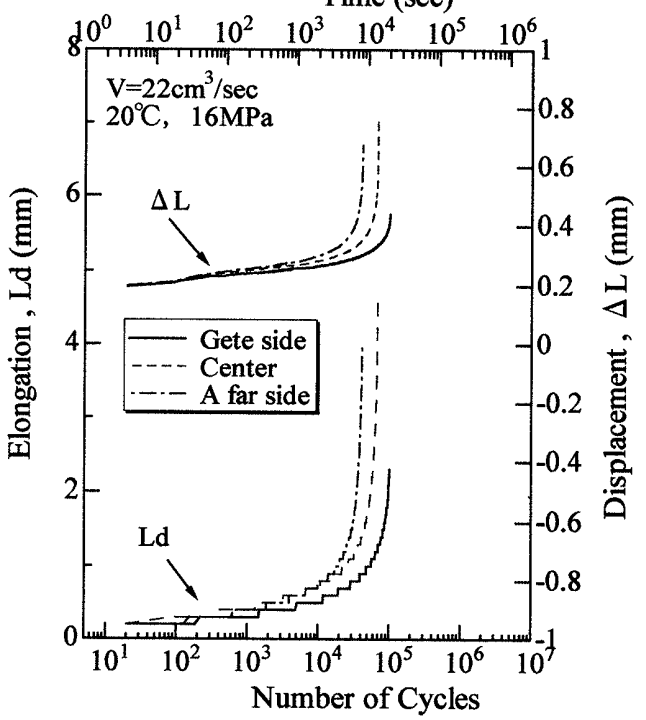

(b) Variations in $\mathrm{Ls}$ and $\Delta \mathrm{L}$ during fatigue process.

Fig.5 Dynamic viscoelastic properties of fatigue process $\left(20^{\circ} \mathrm{C}\right)$

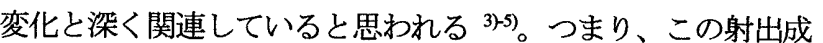
形試料の中閒層は高硬度、高弾性率、高配向度であり、外部負 荷を受ける際、中間層が大きな応力を分担しているため、き裂 の発生と伝播が起こりやすくなると考えられる。

\section{4. まとめ}

本研究は射出成形試料の流れ方向における内部構造と疲 労破壊特性について調べた。その結果は次の通りである。

(1).光学顕微鏡による内部組織の観察では、3 層構造が確認 できたが、流れ方向に向かって、その 3 層構造の顕著な 変化が見えなかった。

(2).流れ方向に向かって試料断面各層の硬さは低下した。

(3).流れ方向に向かって疲労過程中の E'のレベルが低くな り、 $\tan \delta$ のレベルが高くなった。これに伴って疲労寿命 が低下した。

(4).射出成形速度を変えた場合にも各特性の傾向は類似し ていた。

\section{参考文献}

(1).植野、ポリファイル 39-455、(2002).p30.

(2).永田、ポリファイル 39-455、(2002).p52.

(3).邱、川越、水野、森田、機論 A、66-645、(2000).p875. 等 